\title{
Soil erosion risk assessment in the Chaleleka wetland watershed, Central Rift Valley of Ethiopia
}

\author{
Kebede Wolka ${ }^{*}$, Habitamu Tadesse ${ }^{1}$, Efrem Garedew ${ }^{2}$ and Fantaw Yimer ${ }^{1}$
}

\begin{abstract}
Background: Increased flooding and newly formed rills and gullies were observed in the Cheleleka wetland watershed, over the past three to five years. These events are due to problems related to land use changes and are adversely affecting land productivity. This study was conducted to quantify, analyze and map soil erosion risk areas using the Revised Universal Soil Loss Equation.

Results: Only 13.6 percent of the study area has a soil loss value less than 10 ton per hectare per year with the remaining area experiencing a higher soil loss value. A large area, 53.6 percent of the watershed, is under severe to extremely severe soil loss ( $>45$ ton per hectare per year). Another 17.3 percent of the study area has annual soil loss of 20-45 ton per hectare.

Conclusion: A significantly large area of the Cheleleka wetland watershed has non-tolerable soil erosion that threatens annual crop production, land productivity, and hydrological functioning of the area. From the conservation perspective, a large proportion of the watershed needs immediate watershed management intervention.
\end{abstract}

Keywords: Conservation priority; Land use change; Topography; Soil erosion

\section{Background}

Soil erosion is a natural geological phenomenon resulting from the removal of soil particles by water or wind (Gitas et al. 2009). This natural process can be accelerated by human activities creating soil loss that exceeds the soil formation rate in a given area. Human activities that change land use from a comparatively higher form of permanent vegetation cover, to a state of lesser vegetation cover, have increased soil erosion (Cebecauer and Hofierka 2008).

Several studies in Ethiopia have revealed that soil erosion has become an alarming problem (Wagayehu and Drake (2003); Admasu (2005); Bewket and Teferi (2009); Haile and Fetene (2012)) and it is the major factor affecting the sustainability of agricultural production. The leading factors causing erosion include: increased population pressure resulting in forest/woodland clearance for wood and smallholding agriculture; traditional agricultural practices; and declining land productivity.

\footnotetext{
* Correspondence: kebedewolka@gmail.com

${ }^{1}$ Hawassa University, Wondo Genet College of Forestry and Natural Resources, School of Natural Resources and Environmental Studies, P.O.Box 128, Shashemene, Ethiopia

Full list of author information is available at the end of the article
}

In the Cheleleka wetland watershed, large expansions of new land uses were made mostly through the displacement of the original forests and pasture land. For example, using remote sensing and Geographic Information System (GIS) methods, Gessesse (2007), estimated an alarming $82 \%$ forest decline in the area when comparing 1972 forest cover to 2000. In many cases, this conversion occurred without evaluating the land use capacity, thus exposing the new cultivated fields to a high level of degradation. Moreover, the erosion and sedimentation processes disrupt the hydrological balance in the study watershed. In contrast to other lakes in the Rift Valley of Ethiopia, the level of Lake Hawassa has been increasing while the Cheleleka wetland is unfortunately drying up. Thus the increasing discharge from the wetland through the 'TikurWuha' River is partially related to the activities of erosion and the sedimentation processes in the Cheleleka watershed (Gessesse 2007; Tenalem et al. (2007); Kebede et al. (2014)).

Increased flood and erosion risks were investigated as part of the field work for this study (Figure 1). Medo, Burara, and Gotu-Onoma ${ }^{2}$ kebeles were found to be victims of erosion and flooding which damaged large areas of cropland, forming new rills and gullies, and damaged 


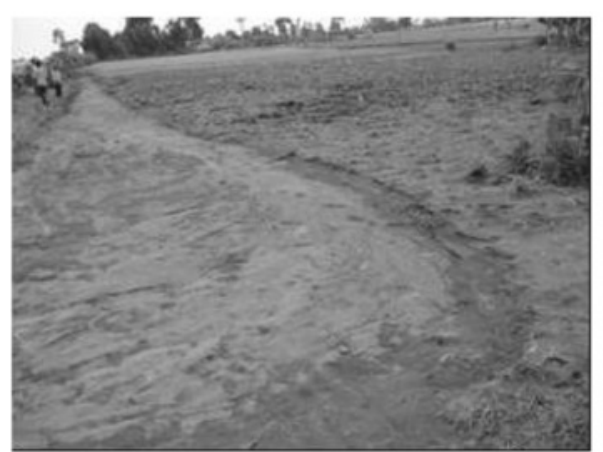

a

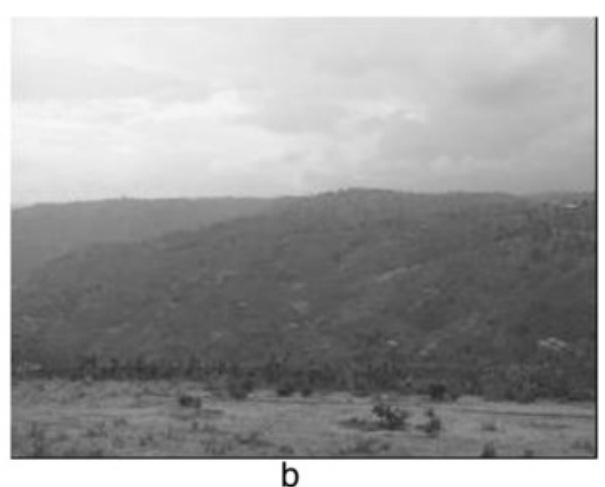

Figure 1 Partial view of the study site ('a'shows erosion site and 'b' shows topography).

ditches along concrete and asphalt roads. Recently, the watershed stream discharge has increased, causing flooding (Kebede et al. 2014). Therefore, the extent and spatial pattern of the watershed's soil erosion needs to be assessed. This will assist the identification of erosion susceptible areas for planning and implementation of a watershed-based soil and water conservation plan. No soil erosion susceptibility analysis and map were available for this watershed. This highly populated, socioeconomically, and hydrological relevant rural watershed, supplying significant water resources to watershed residents and other towns outside the watershed, is in need of assessment and management.

A relevant approach needs to be followed in estimating the spatial variation of soil erosion. In various corners of the globe, scientists apply related approaches and models for estimating soil erosion and related processes. For instance, the Hairsine-Rose model and hysteresis has been applied for estimating soil erosion sediment sizes, water discharge and contamination possibility (Sender et al. 2011). Other methods and approaches such as the Morgan method (Ustun 2008), ImpelERO model (Shahbazi et al. 2010), CORINE methodology (Gupta and Uniyal (2012)), and SWAT model (Gebreyesus et al. (2013)) have been applied. Many other researchers use Revised/ Universal Soil Loss Equation (RUSLE/USLE) (Zhao et al. (2013); Gaatib and Larabi (2014)). This USLE method is preferred to others as it is commonly applied with reliable accuracy at watershed scales when detailed input data are less available (Kheir et al. (2008); (Raissouni et al. (2012)). The RUSLE has capacity to estimate soil erosion by incorporating the environment, having complex and varying gradients (Tongqian et al. 2009).

Although various studies have been conducted within and/or around the Cheleleka watershed (e.g. Gessesse (2007)) none of them have assessed the soil erosion problem using RUSLE. Therefore, this study was designed to quantify, analyze and map soil erosion risk areas within the Cheleleka watershed using the Revised Universal Soil Loss Equation (RUSLE) and GIS tools.

\section{Results and discussions}

The soil loss amount, severity and extents varied for the different parts of the sub watershed. About 13.6 percent of the study area has a soil loss value of less than $10 \mathrm{tha}^{-1} \mathrm{yr}^{-1}$ (Figure 2 and Table 1), mainly along the flat to gentle slopes of the downstream area. Among the sub-watersheds, the downstream areas of the Wedesa, Gemesho, Shonkora and Werka Rivers were dominated by low soil loss values.

More than half of the watershed area (53.6 percent) is experiencing 'severe' to 'extremely severe' soil losses, representing 80.1 percent of the total soil loss from the watershed. This includes the 'Burara-Abaro-Wijigira' mountain chain, and the valleys of the 'Wodesa' River and its tributary, at the upstream part of the watershed (Figures 2 and 3).

'Moderate' soil loss $\left(10-20 \mathrm{t} \mathrm{ha}^{-1} \mathrm{yr}^{-1}\right)$ is observed in 15.5 percent of the watershed, covering the sub-watersheds in Upper Wesha, upper Hallo, and lower Lango. The soil loss severity class of 'high to very high' (20-45 ton/ha/year) occurs in 17.3percent of the total study area.

The soil loss observed in the downstream sections of the Werka, Shenkora, Gemesho and Wedesa areas is, to a certain extent, in the 'tolerable' range, (less than $\left.10 \mathrm{tha}^{-1} \mathrm{yr}^{-1}\right)$. The dominant factor for the retarded soil loss in these areas is the gentle slope gradient that causes reduced runoff velocity. Furthermore, the protective nature of the land use/cover, predominantly the perennial crops such as sugarcane and 'inset' based agroforestry system, could also contribute to arresting soil movement in these areas. A related study in Romania reported tolerable soil loss for watershed areas with lower slope gradients and having good vegetation cover (Arghiuş and Arghiuş 2011). 


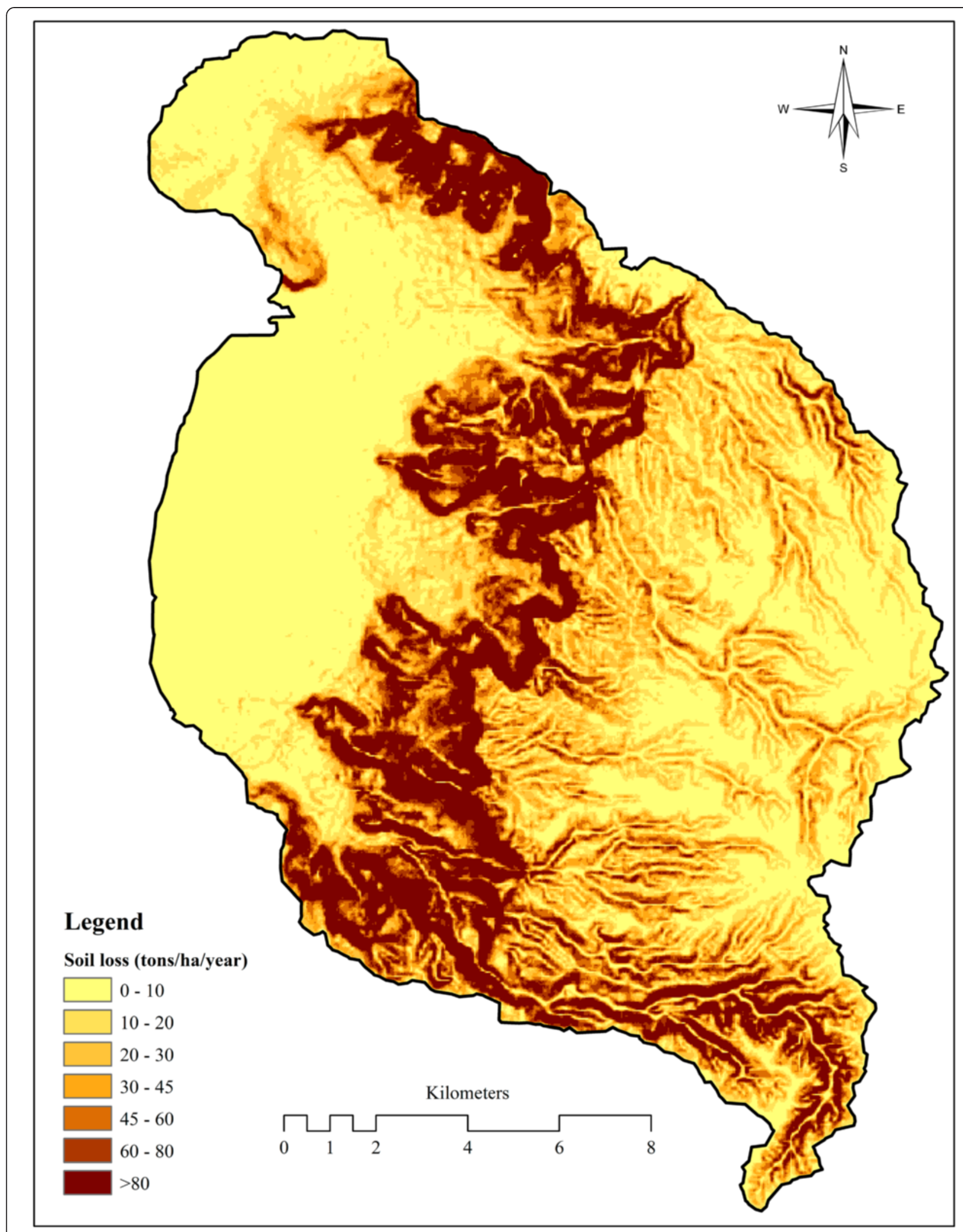

Figure 2 Annual soil loss of Cheleleka wetland watershed. 
Table 1 Soil erosion severity and conservation priority class

\begin{tabular}{|c|c|c|c|c|c|c|c|c|}
\hline ID & $\begin{array}{l}\text { Average soil loss } \\
\left(\mathrm{t} \mathrm{ha}^{-1} \mathrm{yr}^{-1}\right)\end{array}$ & $\begin{array}{l}\text { Erosion } \\
\text { severity class }\end{array}$ & $\begin{array}{l}\text { Priority } \\
\text { class }\end{array}$ & Sub-watershed & Area (ha) & $\begin{array}{l}\text { Proportion by } \\
\text { area (percent) }\end{array}$ & $\begin{array}{l}\text { Annual soil loss } \\
\text { (ton/year) }\end{array}$ & $\begin{array}{l}\text { Proportion of total } \\
\text { soil loss (percent) }\end{array}$ \\
\hline 1 & $2.52-10$ & Low & $\mathrm{VII}$ & $\begin{array}{l}\text { Lower Worka, lower } \\
\text { Shenkora, lower } \\
\text { Gemesho and lower } \\
\text { Wedesa }\end{array}$ & 3689.46 & 13.6 & 23096 & 2.1 \\
\hline 2 & $10-20$ & Moderate & $\mathrm{Vl}$ & $\begin{array}{l}\text { Upper Wesha, upper } \\
\text { Hallo,lower Lango }\end{array}$ & 4203.18 & 15.5 & 63047.7 & 5.8 \\
\hline 3 & $20-30$ & High & V & Medo, Upper Gemesho & 3506.4 & 13 & 87660 & 8 \\
\hline 4 & $30-45$ & Very high & IV & Lower Wosha & 1153.53 & 4.3 & 43257.4 & 4 \\
\hline 5 & $45-60$ & Severe & III & $\begin{array}{l}\text { Upper Worka, lower } \\
\text { Hallo and upper Wedesa }\end{array}$ & 9185.85 & 33.9 & 482257.1 & 44.2 \\
\hline 6 & $60-80$ & Very severe & $\|$ & $\begin{array}{l}\text { Upper Shenkora, middle } \\
\text { Gemesho, middle Wedesa }\end{array}$ & 3896.37 & 14.4 & 272745.9 & 25 \\
\hline \multirow[t]{2}{*}{7} & $80-85.64$ & Extremely severe & 1 & Upper Lango & 1434.15 & 5.3 & 118776.3 & 10.9 \\
\hline & & Total & & & 27068.94 & 100 & 1090840.4 & 100 \\
\hline
\end{tabular}

Owing to elevated land demand resulting from increasing population and comparatively suitable land for cultivation, most marginal land has been economically utilized. In this effort, trees and perennial species planted around rivers can reduce soil erosion at the river bank (Lee et al. 2003). The deep (roughly $50 \mathrm{~cm}$ ) furrowing commonly practiced for growing sugarcane also contributed significantly to reducing soil erosion.

At the upstream areas of Hallo and Wesha, a moderate soil loss rate was observed primarily due to topography. In these areas, soil erodibility and rainfall erosivity is high but good crop cover, especially inset, and low topographic relief, moderated soil loss rate.

Even though rainfall is low, soil is less erodible and better soil conservation practices exist in the Medo area it experiences high soil erosion rates due to topography. High soil erosion upstream from Gemesho is also attributed to the topography, high rainfall and comparatively high soil erodibility.

The watershed area for which the rate of observed soil loss is not tolerable by any standard (Morgan (2005)) is categorized as 'severe, 'very severe' and 'extremely severe' soil loss areas. Such soil loss rates were observed in land areas with comparatively high slope gradients and in areas where the original forest cover has been transformed to arable land and degraded bush land. A report by Raissouni et al. (2012) for Northern Morocco, agrees with this finding, indicating a greater soil loss risk is observed in land area with higher gradient and damaged terrain. During the field work, we noted that only a small portion of the study area (Burara-Medo-Abaro-Wijigira mountain chain and adjacent lands) had highly degraded forest/shrub land compromising the stability of the natural environment. A research project in Cuba reported that conversion from forest to arable land increases soil loss in mountainous watersheds (Schiettecatte et al. 2008), which are fragile environments. The tolerable soil loss in such circumstances is no more than $2 \mathrm{t} \mathrm{ha}^{-1} \mathrm{yr}^{-1}$ (Hudson (1981)). Cebecauer and Hofierka (2008) and Starchi et al. (2013) also observed that land cover has a significant influence on soil erosion patterns in mountainous and hilly areas. A report from China (Luo et al. 2014) indicated that land with lower vegetation cover produced greater runoff and sediment yield implying the extent of soil erosion. Similarly, a Nigerian study by (Oruk et al. 2012) reported greater soil erosion in lands with poor vegetation cover.

The areas susceptib'le to 'severe' to 'very severe' soil erosion have a high rate of agricultural and agroforestry uses dominated by inset and khat farming in the sub-watersheds of the Wesha, Werka, Shonkora, Hallo, Gemesho and Wedesa rivers. This appeared to be a more protective land use than annual cropping systems, which is common for the Upper Lango and Medo areas, where 'very severe' soil loss was observed. Annual cropping leaves the land exposed for off-season grazing, direct rainfall impact and runoff with the resultant soil loss.

In the study area, the increasing population pressure is a serious problem that increases forest land conversion into arable land, leading to land degradation (Gessesse (2007)). Most of the watershed area, with a high LS-factor and low C-factor has 'high' to 'very severe' soil loss values. The combination of these important factors, along with erosive rainfall, contributed to a non-tolerable soil erosion problem. A similar study in China indicates, that in mountainous watersheds, vegetation cover is the most important factor in reducing soil erosion (Zhou et al. (2008); Tongqian et al. (2009). The China's Grain for Green Program attempted to increase land cover and this significantly reduced sediment yield that implies reduction in soil erosion (Zhou et al. 2015). Bewket and Teferi (2009) also observed soil degradation problems, due to erosion, in cultivated 


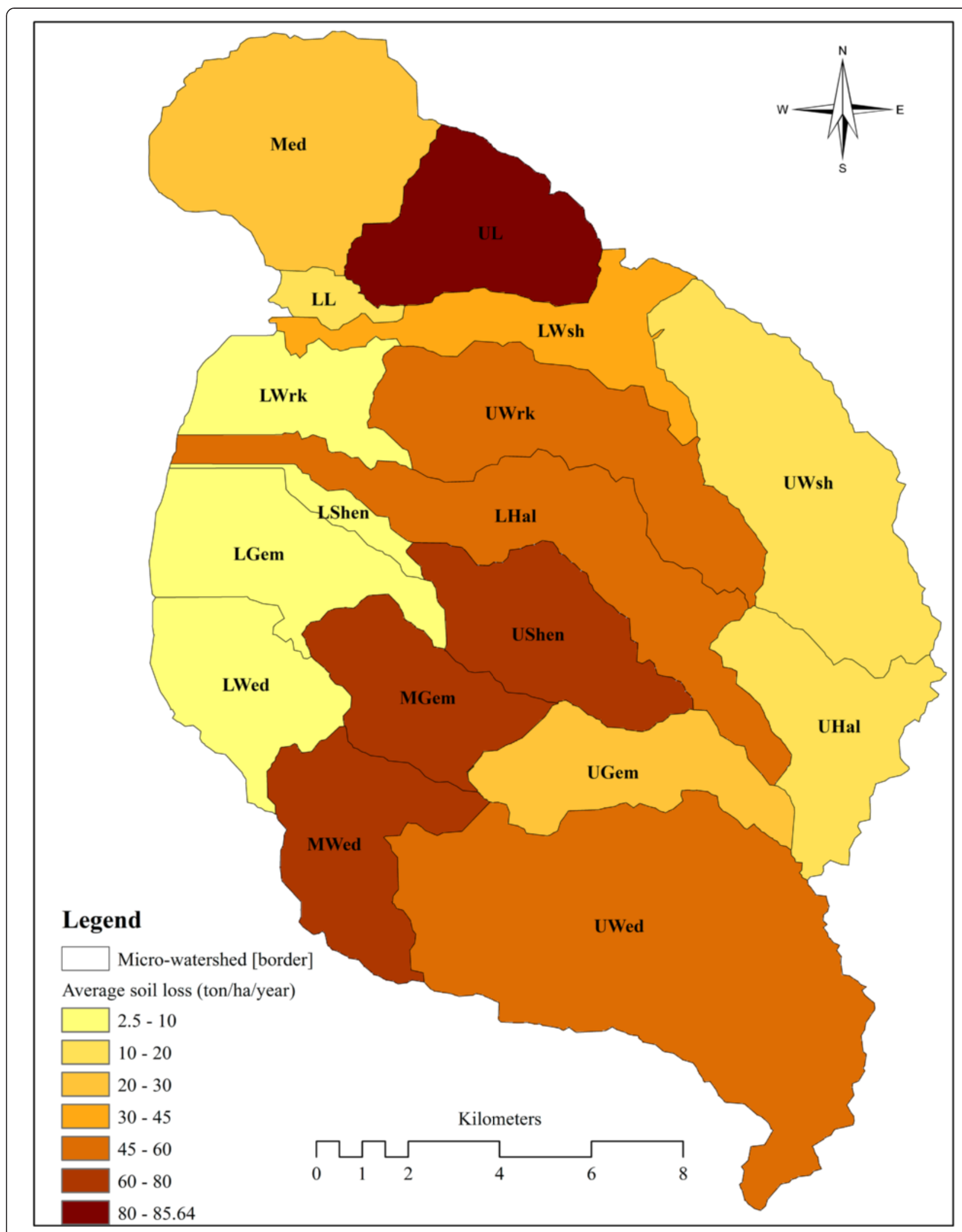

Figure 3 Soil loss severity classification. NB: Med = Medo;LL = Lower Lango; UL = Upper Lango; LWsh = Lower Wesha;UWsh = Upper Wesha; LWrk = Lower Werka; UWrk = Upper Werka; LHal = Lower Hallo; UHal = Upper Hallo; LShen = Lower Shenkora; UShen = Upper Shenkora; LGem = Lower Gemesho; MGem = Middle Gemesho;UGem = Upper Gemesho;LWed = Lower Wedesa; MWed = Middle Wedesa; UWed = Upper Wedesa. 
steep lands of the Blue Nile basin in Ethiopia. The soil erosion susceptibility and risk analysis in Morocco by Gaatib and Larabi (2014) agree with this study's results, in that, watershed areas with 'very low' to 'low' slope gradient showed 'low' to 'moderate' soil erosion susceptibility and risk.

\section{Conclusions}

Using RUSLE in combination with GIS allowed analysis of erosion problems in the Cheleleka wetland watershed. Our findings revealed that the study area is facing forest transformation, which is very likely intensified by the demand for subsistence agricultural land. Most of the parts of this watershed have experienced intensive soil erosion behavior, which is beyond the tolerable soil loss level. This threatens the annual crop production and the productivity of the land impacting the local farmers' food security (Brevik, 2013; Pimentel and Burgess 2013). The erosion may also have off-site consequences in the wetlands and have the possibility to modifying its nature and function (Gleason RA et al. 2003).

In addition, the risk of flooding in the middle and lower part of the watershed may become serious if the protective land use/cover quality is compromised. The risk can be aggravated by steep slopes, high rainfall and poor conservation practices. The increased coverage with khat and inset based agroforestry practices can be considered a positive step to minimize the already intensified soil erosion risk in the watershed. This clearly shows there is a need for immediate action and intervention to protect and sustainably use the natural environment. Integrated watershed management could be a process to direct the intervention and encourage local people to participate in the process.

Maintaining and improving land cover and practicing site specific soil conservation activities are important in reducing soil erosion and its consequences. The current national watershed management campaign can contribute to the success of this recommendation. Within this watershed, the suggested intervention priority (Table 1) should be considered for management implementation.

\section{Methods}

\section{The Cheleleka wetland watershed}

The study was undertaken in the Cheleleka wetland watershed, a sub-watershed of Lake Hawassa Catchment that is partially found in the Central Rift Valley of Ethiopia, $263 \mathrm{~km}$ south of Addis Ababa. The study area was located in a watershed where a chain of mountains stretch out and occupy a wide flat marshy land called Cheleleka. Geographically, it is located between $38^{\circ} 37^{\prime} \mathrm{E}$ to $38^{\circ} 42^{\prime} \mathrm{E}$ and $7^{\circ} 02^{\prime} \mathrm{N}$ to $7^{\circ} 07^{\prime} \mathrm{N}$ (Figure 4). It covers an area of about 27068.94 ha with wide altitudinal ranges of 1600 to 2700 meters above sea level.
Within the watershed some remnant natural forests were identified, which are composed of tree species including: Afrocarpus falcatus, Prunus africana, Albizia gummifera, Aningeria adolfi-friederici, Cordia africana, and Croton macrostachus. Plantation woodlots with exotic tree species such as Eucalyptus species, Gravilea robusta, and Cuprusus lustanica were common. At homestead and farm boundaries, agro-forestry activities are commonly practiced.

Based on Zerihun (1999), the population density of the area was predicted to be 870 persons per square kilometer in 2013, which is much higher than the regional average population density (141 person/sq. km, CSA (Central Statistical Authority of Ethiopia) (2007)).

\section{Methodology}

Among available methods for predicting and quantifying soil erosion risks, RUSLE is widely applied by adapting it to various situations. The Universal Soil Loss Equation (USLE) was initially developed for predicting soil erosion from small areas of cultivated land (Bewket and Teferi (2009)). However, remote sensing and Geographic Information Systems (GIS) are now being integrated into RUSLE, in addition to the soil data, to increase the risk assessment precision.

Initially, the watershed was delineated by considering contour lines pattern on topographic maps that have been produced by Ethiopian Mapping Agency. The delineated map was verified using the GIS Digital Elevation Model (DEM). The watershed was classified into seven slope categories, by percent $(0-2 ; 2-5 ; 5-8 ; 8-16 ; 16-$ 30 ; $30-45$; $>45$ ), for field data collection, particularly for soil sampling, land use/cover description, and for soil and water conservation support practice analysis. The systematic sampling points were uniformly distributed on Universal Transfer Mercator (UTM) grid points using GIS. These points were located in the field with the aid of Global Positioning System (GPS).

\section{Data acquisition}

The Universal Soil Loss Equation (USLE) technique estimates water-caused, soil erosion risk, for varying climatic, soil, and topographic conditions. Since its development, USLE has been continuously improved to more accurately estimate soil loss and to adapt to more situations in a wider range of geographic areas. The Revised Universal Soil Loss Equation (RUSLE) is widely used and is represented by the following general equation:

$$
\mathrm{A}=\text { RKLSCP }
$$

Where A refers to soil loss in $\mathrm{t} \mathrm{ha}^{-1} \mathrm{yr}^{-1}$, $\mathrm{R}$ represents rainfall erosivity, $\mathrm{K}$ represents soil erodibility, $\mathrm{L}$ represent slope length, $\mathrm{S}$ is slope gradient, $\mathrm{C}$ is land cover/use 


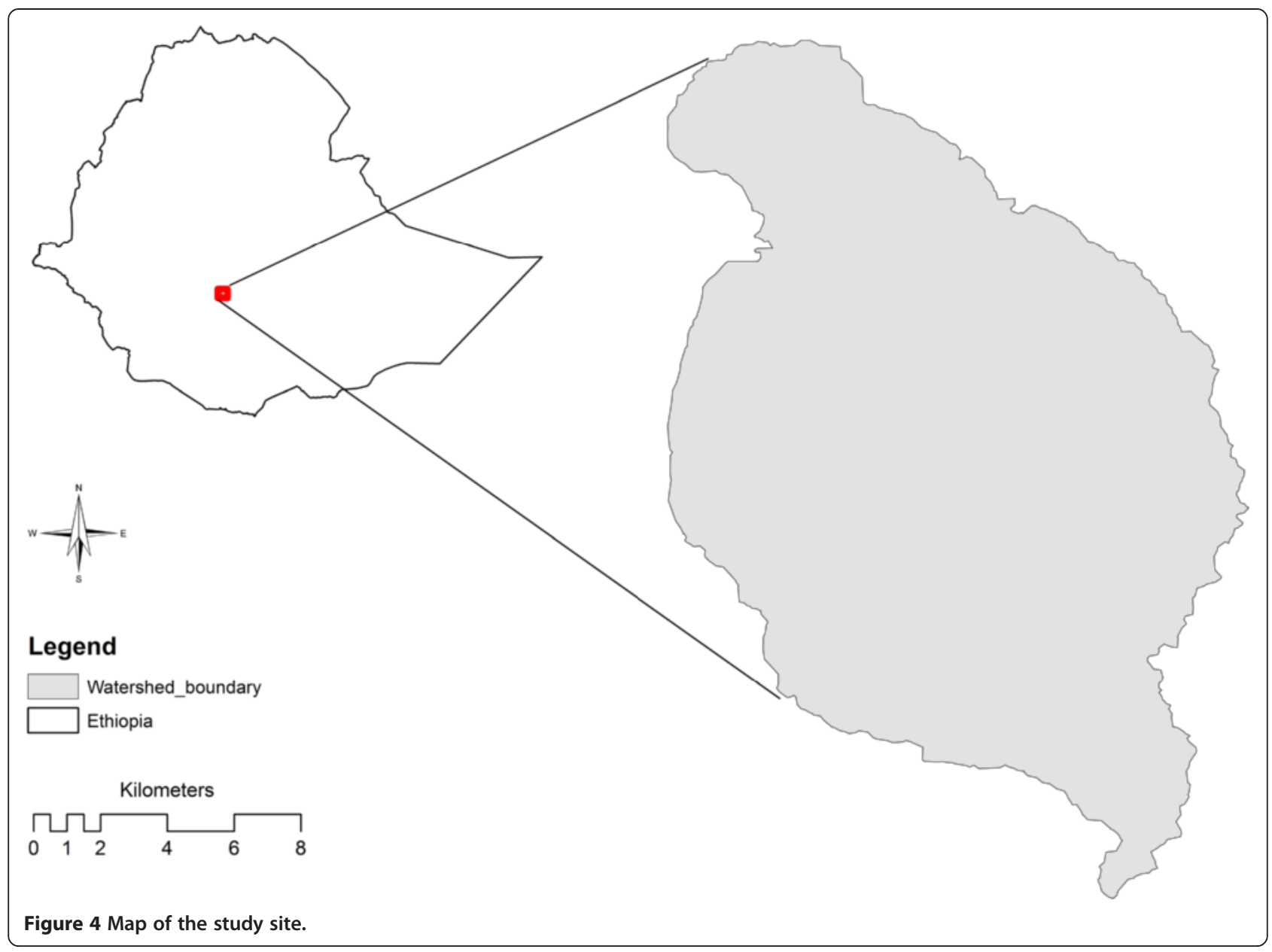

management, and $\mathrm{P}$ is supporting conservation practices. The equation shows that RUSLE is the product of six factors. In this investigation, RUSLE was integrated with GIS to estimate soil loss by exercising appropriate techniques and procedures to acquire relevant data for each of the component parameters as described below.

\section{$R$-factor}

Rainfall regime importantly influences soil loss patterns (Fang et al. (2012)). The erosivity (R) factor quantifies the effect of raindrop impacts. The $\mathrm{R}$-factor requires long term rainfall data that records the energy available to erode soil. Various equations have been adapted to compute the R-factor; one option is that the erosion index for this parameter is calculated from the total storm energy multiplied by maximum 30 minute intensity. For areas that lack long term records of rainfall characteristics, other techniques have been developed for various countries.

Within and around the study watershed, there is no record for rainfall characteristics /intensity. Thus, the $\mathrm{R}$ factor was estimated using rainfall depth data from the meteorological stations within the watershed and those neighboring it. Data from forty years of recorded rainfall at Wondo Genet and four years recorded at the Watera Resa station were available for the study watershed. Meteorological stations at Kofele, Shashemene, and Awassa, which are neighbor to the study watershed, were also considered in this study. Rainfall data recorded at these stations were obtained from the meteorological office. Using mean annual rainfall from these stations, the amount of rainfall between the stations was interpolated using GIS.

Thus, the R-factor was calculated based on the following equation (Bewket and Teferi (2009); Shiferaw (2011)),

$$
\mathrm{R}=-8.12+0.562 \mathrm{P}
$$

Where $\mathrm{R}$ is rainfall erosivity and $\mathrm{P}$ is the mean annual rainfall $(\mathrm{mm})$. This form of the equation for estimating $\mathrm{R}$-factor is particularly used for areas lacking rainfall intensity and kinetic energy records, as is true for many studies performed in Ethiopia.

\section{The K-factor}

The K-factor, or soil erodibility factor, is a critically important component in predicting soil erosion 


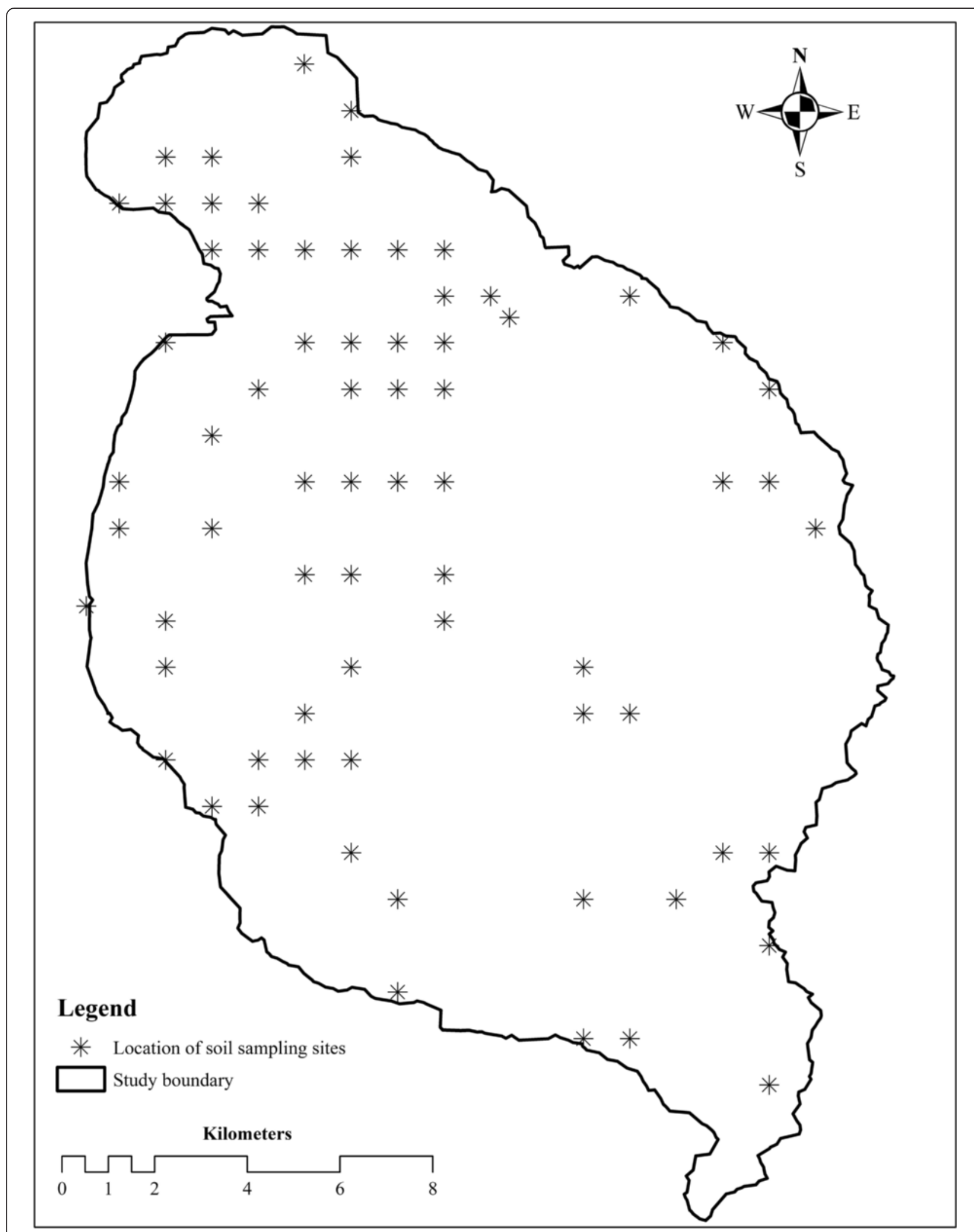

Figure 5 Sampling plots for soil, vegetation description and conservation support practices analysis. 
Table 2 Determination of K-factor from soil organic matter and texture analysis

\begin{tabular}{llll}
\hline Basic textural class & \multicolumn{3}{l}{ Organic matter content } \\
\cline { 2 - 4 } & Average K-factor & $\mathbf{< 2 \%}$ & $\mathbf{> 2 \%}$ \\
\hline Sandy loam & 0.13 & 0.14 & 0.12 \\
Sandy clay loam & 0.2 & 0.2 & 0.2 \\
Clay loam & 0.305 & 0.33 & 0.28 \\
Loam & 0.3 & 0.34 & 0.26 \\
Clay & 0.225 & 0.24 & 0.21 \\
\hline
\end{tabular}

(Oruk et al. (2012); Wang et al. (2013)). According to Wischmeier and Smith (1978), soil organic matter and permeability were integrated into the equation for $\mathrm{K}$.

$$
\mathrm{K}=\left[2.1 .10^{4} \mathrm{M}^{1.14}(12-\mathrm{OM})+3.25(\mathrm{~S}-2)+2.5(\mathrm{P}-3)\right] / 759
$$

Where OM is the soil organic matter (percent) and M is a particle size parameter, which is estimated by multiplying the silt percentage (particles of 0.002 to $0.1 \mathrm{~mm}$ in size) by $100-\%$ clay. The $S$ and $P$ parameters describe soil structure and permeability respectively. When the available or collected data set lacks any of these soil properties alternative methods can be adapted.

To determine soil erodibility ( $\mathrm{K}$ factor), 76 soil samples were collected and analyzed. Sample plots were identified using a grid method at $1 \mathrm{~km}$ intervals both longitudinally and latitudinal (Figure 5). Sample plots were located in the field with the help of GPS. Soil samples were taken at each plot at a depth of $0-20 \mathrm{~cm}$. The samples were air dried at room temperature and analyzed for organic matter utilizing the Wackley-Black Method (Tan (2005)) and for texture, using the hydrometric method (Tan 2005). Using organic matter and soil texture for K-factor estimation was adapted from previous studies (Shiferaw (2011); Pal and Samanta
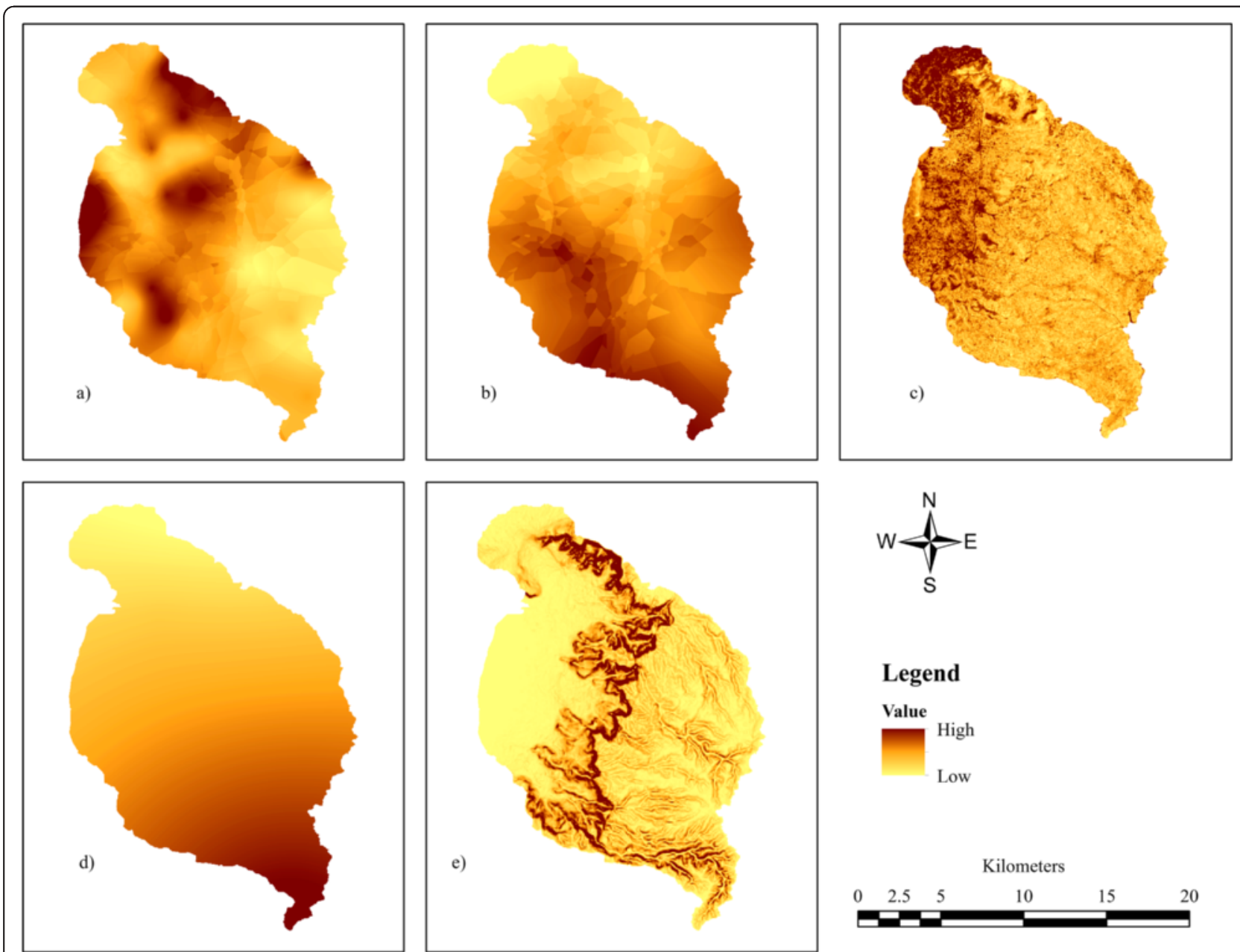

Figure 6 RUSLE's factor maps of erosion control practices (a), soil erodibility (b), crop management (c), rainfall erosivity (d) and topography (e). 
Table 3 P-factor determination

\begin{tabular}{lll}
\hline Land use/support practice & Value for P-factor \\
\hline Agriculture & Slope (\%) & \\
& $0-5$ & 0.1 \\
& $5-10$ & 0.12 \\
& $10-20$ & 0.14 \\
& $20-30$ & 0.19 \\
& $30-50$ & 0.25 \\
Forest and shrub & $50-100$ & 0.33 \\
Strip cropping, cross slope & 0.5 \\
\hline
\end{tabular}

(2011)) as shown in Table 2 below and mapped in Figure 6b.

\section{LS-factor}

Various approaches have been used to estimate the LS (topographic) factor. Previously, USLE was assumed to apply to small areas where measuring the slope gradient and length was possible and practical. Since this study covers an area of 27068.94 ha, it is difficult to measure each slope's length. Therefore, Digital Elevation Model (DEM) and GIS techniques were used to obtain both slope gradient (S) and slope length (L) (Bewket and Teferi (2009); Nekhay et al. (2009)).

The LS- factor was calculated based on the following equation (Tessema 2011):

$$
\mathrm{LS}=\left(\lambda^{0.3} / 22.1\right) *(\mathrm{~S} / 9)^{1.3}
$$

Where $\lambda$ signifies the flow length and $S$ is slope in percent. Figure 6e indicates map of the LS factor.

\section{C-factor}

The C-factor shows land cover/vegetation management. It is the most important factor in reducing soil erosion activities especially in mountainous watersheds (Zhou et al. 2008; Beskow et al. 2009). The land cover may vary in type including forest, shrub land, agricultural crops, and others. Various techniques have been applied to estimate the C-factor. One option is to compute the Normalized Difference Vegetation Index (NDVI) from satellite images in a GIS environment. This is a widely applied technique to estimate vegetation growth and it was confirmed to produce optimal $C$ factor value (Karaburun 2010). The difference in spectral reflectance between the Near Infrared (NIR) and Red (R) bands are used to calculate NDVI (Arekhi et al. 2012):

$$
N D V I=\frac{N I R-R}{N I R+R}
$$

The NDVI indicates photosynthetic capacity and when there is healthy vegetation with good photosynthetic ability, it is positive when the land is bare or vegetation is in the dormant period, the NDVI value is negative. In general, the NDVI ranges from -1 to 1 . The relationship between the C-factor and NDVI can be established as follows (Arekhi et al. 2012):

$$
C=\left(1-\frac{N D V I}{2}\right)
$$

Figure 6c indicates map of the NDVI.

\section{P-factor}

During the soil sampling process, the existing land use/ support practices around the sample plots were assessed and recorded. The values suggested for the P-factor are presented in Table 3 (Wischmeier and Smith 1978) (Figure 6a).

Eventually, the risk of soil loss was quantified for the watershed by multiplying the six component parameters, via GIS, and the extent of soil loss per hectare per year is shown.

\section{Endnote}

${ }^{a}$ Kebele is the lowest government structure in the country.

\section{Abbreviations}

CSA: Central Statistical Authority; DEM: Digital Elevation Model; GIS: Geographic Information system; GPS: Global positioing system; NDVI: Normalized Difference Vegetation Index; NIR: Near Infrared; RUSLE: Revised Universal Soil Loss Equation; USLE: Universal Soil Loss Equation; UTM: Universal Transfer Mercator.

\section{Competing interests}

The authors declare that they have no competing interests.

\section{Authors' contributions}

KW: participated in designing the research idea, field data collection, data analysis, interpretation and report writing; HT: participated in field data collection, modeling of the data in GIS; EG: contributed in field data collection, structuring the report; FY: participated in designing the method and structuring the report. All authors read and approved the final manuscript.

\section{Authors' information}

Kebede Wolka: Assistant professor at Hawassa University, Wondo Genet College of Forestry and Natural Resources. He teaches and undertakes research on soil science, soil erosion, soil and water conservation and watershed management. He has published 8 articles mainly in international journals.

Habtamu Tadesse: lecturer at Hawassa University, Wondo Genet College of Forestry and Natural Resources. He teaches and undertakes research on GIS He has published one article with previous author and other colleagues. Efrem Garedew (PhD): specializes on land use change, land evaluation and livelihood.

Fantaw Yimer (PhD): Associate professor in soil science, Hawassa University, Wondo Genet College of Forestry. He has published many articles in international journals. 


\section{Acknowledgement}

Hawassa University, Wondo Genet College of Forestry and Natural Resources provided financial support for field data collection and soil laboratory analysis. The authors thank Tatum Branaman and Bob Sturtevant for language editing. The authors thank anonymous reviewers for constructive comments.

\section{Author details}

${ }^{1}$ Hawassa University, Wondo Genet College of Forestry and Natural Resources, School of Natural Resources and Environmental Studies, P.O.Box 128, Shashemene, Ethiopia. ${ }^{2}$ Hawassa University, Wondo Genet College of Forestry and Natural Resources, School of Forestry, P.O.Box 128, Shashemene, Ethiopia.

Received: 14 November 2014 Accepted: 10 March 2015 Published online: 08 April 2015

\section{References}

Admasu A (2005) Study of sediment yield from the Watershed of Angereb reservoir. MSc thesis, Department of Agricultural Engineering, Alemaya University, Ethiopia

Arekhi S, Darvishi AB, Shabani A, Fathizad H, Ahamdyasbchin S (2012) Mapping soil erosion and sediment yield susceptibility using RUSLE, remote sensing and GIS (Case study: Cham Gardalan Watershed, Iran). Adv Environ Biol 6(1):109-124

Arghiuş C, Arghiuş V (2011) The quantitative estimation of the soil erosion using USLE type ROMSEM model: Case-study-the Codrului ridge and Piedmont (Romania). Carpathian J Earth Environ Sci 6(2):59-66

Beskow S, Mello CR, Norton LD, Curi N, Viola MR, Avanzi JC (2009) Soil erosion prediction in the Grande River Basin, Brazil using distributed modeling. Catena 79:49-59

Bewket W, Teferi E (2009) Assessment of soil erosion hazard and prioritization for treatment at the watershed level: case study in the Chemoga watershed, Blue Nile basin, Ethiopia. Land Degrad Dev 20:609-622

Brevik EC (2013) The potential impact of climate change on soil properties and processes and corresponding influence on food security. Agriculture 3(3):398-417

Cebecauer T, Hofierka J (2008) The consequences of land-cover changes on soil erosion distribution in Slovakia. Geomorphology 98:187-198

CSA (Central Statistical Authority of Ethiopia) (2007) Report of population and housing census. Addis Ababa, Ethiopia.

Fang N, Shi Z, Li L, Guo Z, Liu Q, Ai L (2012) The effects of rainfall regimes and land use changes on runoff and soil loss in a small mountainous watershed. Catena 99:1-8

Gaatib R, Larabi A (2014) Integrated evaluation of soil erosion hazard and risk management in the Oued Beht watershed using remote sensing and GIS techniques: impacts on El Kansra Dam Siltation (Morocco). J Geogr Inf Syst 2014(6):677-689

Gebreyesus BT, Vlek PG, Lulseged T (2013) Application of SWAT model to assess erosion hotspot for sub-catchment management at Mai-Negus catchment in northern Ethiopia. East Afr J Sci Tech 2(2):97-123

Gessesse D (2007) Forest Decline in South Central Ethiopia: Extent, History, and Process. Ph.D. thesis, Stockholm University, Stocholm, Sweden

Gitas IZ, Douros K, Minakou C, Silleos GN, Karydas CG (2009) Multi-temporal soil erosion risk assessment. In: Chalkidiki N (ed) Using a modified USLE raster model. EARSeLe Proceedings 8, 1/2009., pp 40-52

Gleason RA E Jr, Hubbard DE, Duffy WG (2003) Effects of sediment load on emergence of aquatic invertebrates and plants from wetland soil egg and seed banks. Wetlands 23(1):26-34

Gupta P, Uniyal S (2012) A case study of Ramgad watershed, Nainital for soil erosion risk assessment using CORINE methodology. Int J Eng Res Technol 1(10):1-7

Haile GW, Fetene M (2012) Assessment of soil erosion hazard in kilie catchment, east shoa, Ethiopia. Land Degrad Dev 23:293-306

Hudson NW (1981) Soil Conservation. Batsford, London

Karaburun A (2010) Estimation of C factor for soil erosion modeling using NDVI in Buyukcekmece watershed. Ozean J Appl Sci 3(1):77-85

Kebede W, Tefera M, Alemayehu T, Habtamu T (2014) Impact of land cover change on water quality and stream flow in lake Hawassa watershed of Ethiopia. Agric Sci 5:647-659
Kheir RB, Abdallah C, Runnstrom M, Mart-Ensson U (2008) Designing erosion management plans in Lebanon using remote sensing, GIS and decision-tree modeling. Landsc Urban Plan 88(2-4):54-63

Lee KH, Isenhart TM, Schultz RC (2003) Sediment and nutrient removal in an established multi-species riparian buffer. J Soil Water Conserv 58(1):1-7

Luo Z, Deng L, Yan C (2014) Soil erosion under different plant cover types and its influencing factors in Napahai Catchment, Shangri-La County, Yunnan Province, China, International. J Sustain Dev World Ecol, doi:10.1080/ 13504509.2014 .924448$.

Morgan RPC (2005) Soil Erosion and Conservation (3rd edn). Blackwell Science, Oxford

Nekhay O, Arriaza M, Boerboom L (2009) Evaluation of soil erosion risk using Analytic Network Process and GIS: a case study from Spanish mountain olive plantations. J Environ Manage 90:3091-3104

Oruk EO, Eric NJ, Ogogo AU (2012) Influence of soil textural properties and land use cover type on soil erosion of a characteristic ultisols in Betem, Cross River Sate, Nigeria. J Sustain Dev 5(7):104-110

Pal B, Samanta S (2011) Estimation of soil loss using remote sensing and geographic information system techniques: Case study of Kaliaghai River basin, Purba \& Paschim Medinipur District, West Bengal, India. Indian J Sci Technol 4(10):1202-1207

Pimentel D, Burgess M (2013) Soil erosion threatens food production. Agriculture 3(3):443-463

Raissouni A, Khali Issa L, El Arrim A, Maâtouk M, Passalacqua R (2012) GIS-based model to assess erosion sensitivity in Northern Morocco. Laou watershed case study. Int J Geosci 3:610-626

Schiettecatte W, D'hondt L, Cornelis WM, Acosta ML, Leal Z, Lauwers N, Almoza Y, Alonso GR, Díaz J, Ruíz M, Gabriels D (2008) Influence of land use on soil erosion risk in the Cuyaguateje watershed (Cuba). Catena 74:1-12

Sender GC, Zheng T, Heng P, Zhong Y, Barry DA (2011) Sustainable soil and water resources: modeling soil erosion and its impact on the environment. 19th International Congress on Modelling and Simulation, Perth, Australia, 12-16 December 2011. http://mssanz.org.au/modsim2011

Shahbazi F, Jafarzadeh AA, Rosa DD, Anaya-Romero M (2010) Soil erosion assessment and monitoring by using ImpelERO model in east Azerbaijan province, Iran. 19th World Congress of Soil Science, Soil Solutions for a Changing World. 1 - 6 August 2010, Brisbane, Australia

Shiferaw A (2011) Estimating soil loss rates for soil conservation planning in the Borena woreda of south Wollo highlands, Ethiopia. J Sustain Dev Afr 13(3):87-106

Starchi S, Freppaz M, Godone D, Zanini E (2013) Assessing the susceptibility of alpine soils to erosion using soil physical and land indicators. Soil Use Manag 29(4):586-596

Tan HK (2005) Soil Sampling, preparation, and analysis. 2nd edition. Taylor \& Francis.

Tenalem A, Robert B, van Arno L, Yemane G, Dagnachew L, Japheth O (2007) Hydrodynamics of topographically closed lakes in the Ethio-Kenyan Rift: The case of lakes Hawassa and Naivasha. J Spat Hydrol 7(1):81-100

Tessema I (2011) Soil Erosion Risk Assessment with RUSLE and GIS in Dire Dam Watershed. Masters thesis, Environmental Science, Addis Ababa University, Ethiopia

Tongqian Z, Bosu Y, Hua Z (2009) Assessment of the erosion control function of forest ecosystems based on GIS: a case study in Zhangjiajie National Forest Park, China. Int J Sustain Dev World Ecol 16(5):356-361

Ustun B (2008) Soil erosion modelling by using GIS \& Remote Sensing: a case study, Ganos mountain. The International Archives of the Photogrammetry, Remote Sensing and Spatial Information Sciences Vol. XXXVII. Part B7, Beijing

Wagayehu B, Drake L (2003) Soil and water conservation decision behavior of subsistence farmers in the Eastern Highlands of Ethiopia: a case study of the Hunde-Lafto area. Ecol Econ 46:437-451

Wang B, Zheng F, Römkens M, Darboux F (2013) Soil erodibility for water erosion: a perspective and Chinese experiences. Geomorphology 187:1-10

Wischmeier WH, Smith DD (1978) Predicting Rainfall Erosion Losses: A Guide to Conservation Planning. United States Department of Agriculture, Washington, p 58

Zerihun M (1999) Natural resource competition and Inter ethnic relations in Wondo Genet, South central Ethiopia. M.Sc. Thesis, Addis Ababa University, Addis Ababa

Zhao W, Fu B, Qui Y (2013) An upscaling method for cover-management factor and its application in the loess Plateau of China. Int J Environ Res Public Health 10:4752-4766 
Zhou P, Luukkanen O, Tokola T, Nieminen J (2008) Effect of vegetation cover on soil erosion in a mountainous watershed. Catena 75:319-325

Zhou ZC, Gan ZT, Shangguan ZP, Dong ZB (2015) China's Grain for Green Program has reduced soil erosion in the upper reaches of the Yangtze River and the middle reaches of the Yellow River. Int J Sustain Dev World Ecol 16(4):234-239

Submit your manuscript to a SpringerOpen ${ }^{\odot}$ journal and benefit from:

- Convenient online submission

- Rigorous peer review

- Immediate publication on acceptance

- Open access: articles freely available online

- High visibility within the field

- Retaining the copyright to your article

Submit your next manuscript at $\gg$ springeropen.com 